WHY IS PIQUANT/SPICY FOOD SO POPULAR?

\title{
Why is piquant/spicy food so popular?
}

Charles Spence, Crossmodal Research Laboratory

Department of Experimental Psychology, University of Oxford, Oxford, UK

WORD COUNT: 8,500 WORDS

SUBMITTED TO: INTERNATIONAL JOURNAL OF GASTRONOMY \& FOOD SCIENCE

DATE: $17^{\text {th }}$ February 2018

Correspondence to: Charles Spence, Department of Experimental Psychology, University of Oxford, Oxford, OX1 3UD, UK.

E-mail: charles.spence@psy.ox.ac.uk 


\begin{abstract}
The desire for piquant/spicy food has grown phenomenally over the last 500 years or so. In this review, I summarize the literature on this most intriguing of oral sensations, and summarize various explanations for why it may have become so liked by so many peoples around the world in recent years. A number of alternative hypotheses for the rise in popularity of this plant/fruit have been put forward and are briefly discussed. These include the masochistic/thrill-seeking hypothesis, the antimicrobial hypothesis, the thermoregulation/salivation-induction hypotheses, and medicinal/health/diet-based accounts.
\end{abstract}

KEYWORDS: Chemesthesis; Masochism; Thrill-seeking; Anti-microbial; Health/Weight Control. 


\section{$\underline{\text { Introduction }}$}

The perception of spiciness (or piquancy; these terms will be used interchangeably in this piece) in a dish, while widely liked by many people around the world, has not received anything like as much research interest from the multisensory or, for that matter, sensory science, communities as have, for instance, the basic tastes (sweet, sour, salty, bitter, and umami) or common flavour experiences. Indeed, it was Harry Lawless (1989) who first described pepper potency as "the forgotten flavour sense" in the title of one of his articles. This seeming neglect is somewhat surprising given that hot pepper (red or green) of the genus Capsicum (family Solanaceae) is one of the world's most widely-used spices, ${ }^{1}$ found in thousands of recipes, and also sometimes eaten as a stand-alone item/dish (see Govindarajan \& Sathyanarayana, 1991; Lembeck, 1987, cited in Abdel-Salam, 2016; Perry, Dickau, Zarrillo, Hoist, Pearsall, Piperno, et al., 2007; Sherman \& Billing, 1999). In fact, according to Cordell and Araujo (1993), one in every four people on the planet currently eat chillies on a daily basis. ${ }^{2}$

The academics continue to argue as to whether or not spiciness/piquancy constitutes a constitutive component of our multisensory flavour experiences (e.g., Gorman, 2010; Green, 1996; Spence, 2012; see Spence, Smith, \& Auvray, 2015, for a review). Given its widespread occurrence across many of the world's cuisines, as well as its potential role in weight management (see below), further research is sorely needed in order to gain a better understanding of this most unique and desirable of oral sensations. One of the problems for researchers in this area, though, is that there is currently no adequate animal model, given that the latter do not spice their food (Sherman \& Billing, 1999). Or, as Paul Bloom puts it in his best-selling book How Pleasure Works: "Man is the only animal that likes Tabasco sauce" (Bloom, 2011, p. 52, as cited in Gorman, 2010). That said, there is some evidence that chimps and rats can both acquire a liking for piquant foods following social exposure to others eating such stimuli (Galef, 1989; Rozin \& Kennel, 1983).

According to Fraenkel (1959), capsaicin should be considered a secondary plant substance, one that is produced by plants in order to prevent their predation by insects (this ecological

\footnotetext{
${ }^{1}$ As Sherman and Billing (1999) note, 'spice' is a culinary term and not a specific botanical category (Farrell, 1990).

${ }^{2}$ According to Miller \& Harrisson (1991, p. 6): "Even the spelling of the word chile gets confusing, as it variously appears as chili and chilli. These alternative spellings depend on how the word is used, on what part of the country you're in, and even on personal whim! The general convention for proper usage is that chile refers to the plant or pod, while chili refers to the traditional dish containing meat and chilies (and sometimes beans), and chilli is the commercial spice powder that contains ground chiles along with a number of other seasonings."
} 
phenomenon also known as 'directed deterrence'; Tewksbury \& Nabham, 2001). More recently, however, it has been suggested that capsaicin might actually be produced by chilli plants in order to repel a particular type of fungus, specifically the Fusarium fungus (see Tewksbury, Reagan, Machnicki, Carlo, Haak, Calderón Peñaloza, \& Levey, 2008). The latter happens to be the number one cause of mortality of chilli seeds prior to their dispersal. Separately, it has been noted that birds are insensitive to capsaicin (Jordt \& Julius, 2002; Tewksbury, \& Nabhan, 2001; Tewksbury, Nabhan, Norman, Suzan, Tuxill, \& Donovan, 1999), and constitute the primary vehicles for seed dispersal in the wild. Herbivores, by contrast, are unlikely to eat the fruit due to the oral burn it induces. That said, when present in suitable concentration, capcaisin may actually inhibit seed germination (Barchenger \& Bosland, 2016).

At the outset, one needs to explain why it is that people enjoy what is, at first glance, an irritating, and potentially painful (and hence, one would have to imagine, 'to-be-avoided') mouth sensation. No one, after all, is born liking spiciness! Rather, people learn to like the oral burn associated with eating moderately hot chilli peppers (Lawless, Rozin, \& Shenker, 1985; Rozin, 1990). The piquancy/spiciness of hot peppers is primarily attributable to the presence of capsaicin (trans-8-methyl- $N$-vanillyl-nonenamide; Surh \& Lee, 1996), a pungent vanilloid compound and dihydrocapsaicin (Nolden \& Hayes, 2017). According to Surh and Lee, the capsaicin content of green and red peppers ranges from 0.1 to $1 \%$. That said, in recent decades, selective breeding (and careful control of the growing conditions) has resulted in the development of some varieties of chilli plant that are much, much more potent (e.g., see Bodkin, 2017; Miller \& Harrisson, 1991).

Capsaicin is a potent agonist of the heat receptor TRPV1. In 1997, Caterina, Schumacher, Tominaga, Rosen, Levine, and Julius discovered that capsaicin is transduced by a heatactivated ion channel in the pain pathway. As the authors put it: "the molecular target of capsaicin action on sensory neurons is a proteinaceous ion channel. VR1..." (Caterina et al., 1997, p. 822). The burn of capsaicin is estimated on the Scoville Scale, in units known as Scoville Heat Units (Scoville, 1912). Basically, the amount by which a sample has to be diluted before the presence of capsaicin can no longer be tasted by a majority of tasters provides the SHU. According to Gorman (2010), bell peppers score 0 on the Scoville scale, while jalapenos come in at somewhere between 5,000 and 50,000, and orange habaneros at 100,000-350,000 SHU. The hottest Indian jolokia peppers can reach 1,000,000 SHUs. Until recently, the world record for the hottest variety of chilli was held by the Carolina Reaper chilli from North America, coming in at around 2,200,000 SHUs. However, in 2017, a new variety of chilli 
pepper, the Dragon's Breath chilli, grown by a Welsh farmer was crowned the world's hottest, coming in at an astronomical (2,500,000 SHU; see Bodkin, 2017). Note here, though, that chillies this powerful are more likely to find a role in chemical deterrents and commercial anaesthetics (e.g., for those who are allergic to conventional drugs) than in cuisine. Indeed, according to the experts, anyone who accidentally swallowed one of these would be in danger of dying from anaphylactic shock (see Holmes, 2017, for the pained response endured by one miner who dared to eat a Carolina Reaper recently without drinking anything for three minutes).

\section{Why do so many people find the irritation/burn of chilli appealing?}

Over the years, several different accounts have been put forward to try and explain why it is that chilli should have become such a desirable component/ingredient of many foods/dishes around the world. After all, peppers, chilli, and paprika were all originally New World plants (native to Mexico, Central \& South America), being introduced to Europe only following Columbus. ${ }^{3}$ Thereafter, the capsicum rapidly spread to Southern Asia, the Far East, and Africa (Lembeck, 1987, cited in Abdel-Salam, 2016; Zohary \& Hopf, 1994). It has been suggested that a number of Asian cultures adopted chillies into their cuisine within a matter of decades of this plant's arrival. It is amazing to consider, then, how a little over 500 years later, chilli has become such a central element, adding spice to the cuisines of many countries/cultures around the globe. Perhaps nowhere more so than Mexico (see Adapon, 2008; Lomelí, 1991; Muñoz Zurita, 1996; van Rhijn, 1993; cf. Calvino, 2009). ${ }^{4}$ That said, it is hard to imagine what the spicy cuisines of Thailand and certain parts of the Indian subcontinent would have been

\footnotetext{
${ }^{3}$ The plant was called pepper because of its similar effect on the flavour of food to the pepper from the East (see McGee, 1984/2004, p. 420; Weil, 1976). Pepper being what Christopher Columbus was trying to find on his voyage West (Fernández-Armesto, 1991; Standage, 2009, pp. 85-91). One might think of this fruit being given the name as an example of wishful thinking! Whatever the reason, the name stuck and, as it turns out, both capsaicin and piperine, the active ingredient that gives black pepper its pungency, are robust chemesthetic stimulants (Green \& Rentmeister-Bryant, 1998). Columbus wasn't especially interested in the chilli plant, given that it could be grown easily in a variety of climates (hence offering less opportunity to control the market). Indeed, it was one of the first plants to be domesticated in the New World (Perry et al., 2007). Today, however, McGee (1984/2004, p. 418) estimates that world production and consumption of chilli is at least twenty times that of the other pungent spice, black pepper, this hinting at its rise in popularity.

${ }^{4}$ Indeed, "Without chile, Mexicans do not believe that they are eating." is a famous Mexican quote (Adapon, 2008, p. 46). Or take the following from New York restaurateur Zarela Martínez (1992, p. 218): "Chile is history. It has outlasted religions and governments in Mexico. It is part of the landscape, literally ... it belongs to the holy trinity that has always been the basis of our diet: corn, beans, and chile."
} 
like before the arrival of chilli plant (Weil, 1976). ${ }^{5}$ Historically-speaking, eating spicy food (here, though, we are talking about spices in general, e.g., including such Medieval favourites as nutmeg, cloves, and cinnamon) may have served as a sign of high social status (e.g., Schivelbusch, 2005). Nowadays, though, an ability to consume very spicy food (in terms of its SHU) is more often used as a sign of one's masculinity in certain countries/cultures where it isn’t already a staple part of the diet, e.g., the US (see Rozin \& Schiller, 1980).

Microfossils found at several sites from the Caribbean down to Sothern Peru show that the chilli plant has been cultivated for at least 6000 years (Paran \& van der Knapp, 2007; Perry et al., 2007). Intriguingly, at all the sites studied by Perry and her colleagues, this plant cooccurred with maize, suggesting what the authors call 'an ancient Neotropical plant food complex'. And, in contrast to the antimicrobial hypothesis put forward by Sherman and Billing (1999), this use of chillies would seem to have more to do with spicing-up a bland food (Rozin, 1987). Similarly, in the present day, chillies are added as much for flavour as anything else. For, as Harold McGee (1984/2004, p. 418) notes, Mexican cuisine, which has one of the most advanced chilli cultures, often involves the blending of several different varieties in order to achieve a specific flavour profile (in Mexico, for instance, chillies are primarily added to the the food, or provided as a condiment, in order to add flavour, rather than piquancy; see Miller \& Harrisson, 1991). One should also not forget that hot peppers also provide an excellent source of vitamins A and C (Rozin, 1987).

According to the archaeological record, the original Capsicums were most probably grown in Bolivia (Allen, 2011, p. 92; Tewksbury et al., 2008). By 6,000 years ago or so, there were already at least five distinct varieties of chilli being grown across the region. According to Harold McGee (1984/2004, p. 419), there are about 25 different species of Capsicum, though only five have been domesticated (Eshbaugh, Janick, \& Simon, 1993). Today, though, most of the chillies eaten come from just one species known as Capsiucum annuum, first cultivated in Mexico more than 5,000 years ago (see also Bosland \& Votava, 2012).

\section{Why do "Some like it hot"?: Learning to like the oral burn of capsaicin}

\footnotetext{
${ }^{5}$ Or, as Tu et al. (2016, p. 52) note: "Trigeminal sensation creates the "heat" consumers feel and taste in the wide number of spicy foods that have become a mainstay of many culinary foodways. For example, in China, spicy foods are sold ubiquitously in street stalls, restaurants, grocery markets and convenience stores. This near universal preference for spicy food is summed up in the Chinese proverb: "Without chili peppers, a dish just can't be delicious.", "
} 
One of the most striking aspects of people's responses to the oral burn associated with the ingestion of capsaicin is just how much individual difference there is in terms of people's liking for such spiciness in their food. There is more individual variation here than for pretty much any other kind of oral sensation associated with eating/drinking. Importantly, these differences concern not just the hedonic response to capsaicin (i.e., do I like this burning sensation or not?) but also the sensory-discriminative ratings of perceived intensity as well. Where, one might well wonder, do such individual differences come from (Rozin, Ebert, \& Schull, 1982)? Well, the research tends to suggest that an individual's propensity to acquire a liking for the burn of capsaicin depends on a range of genetic, personality, and cultural factors (see also Dalton \& Byrnes, 2016). It has even been suggested that individual differences in salivary flow might play a role here too (e.g., Nasrawi \& Pangborn, 1990; Rozin, Mark, \& Schiller, 1981). However, that said, the latter suggestion seems to have fallen out of favour in recent years. According to Gary Nabham (2004) in Why some like it hot, genes, diet, and culture provide the answer.

A Finnish study of 331 pairs of adult twins, for instance, revealed that $18-58 \%$ of the preference for spicy food could be explained by shared genetic influence (Törnwall, Silventoinene, Kaprio, \& Tuorila, 2012). Some researchers have argued that the preference for spicy food is influenced by both taste phenotype and oral anatomy (e.g., Bartoshuk, 1993). Relevant here, supertasters (e.g., those with a propensity toward having a higher density of taste buds; Miller \& Reedy, 1992; though see Garneau, Nuessle, Sloan, Santorico, Coughlin, \& Hayes, 2014) are thought to experience a more intense burn in response to the ingestion of capsaicin, at least on the tip of the tongue (e.g., Bartoshuk, 1993; Karrer, Bartoshuk, Conner, Fehrenbaker, Grubin, \& Snow, 1992). That said, Törnwall et al.’s research failed to demonstrate any link between taster status and a preference for chilli in their Finnish twin sample.

Intriguingly, some percentage of the population has also been reported to experience a bitter taste in response to the delivery of capsaicin (see Green \& Hayes, 2003, 2004). Given that none of us are born liking bitter foods, this individual difference might also be expected to help explain why it is that some like it hot and others do not.

According to some researchers, personality traits (such as 'sensation seeking') seem to play a role in chilli liking too (Byrne \& Hayes, 2013, 2015, 2016; Logue \& Smith, 1986; Stevens, 1990; Terasaki \& Imada, 1988; Wheeler \& Berger, 2007). However, by contrast, Ludy and Matter (2012) argue that it is exposure, not personality (extraversion-introversion, sensation seeking, or finickiness) that best predicts a person's preference for spicy food. In general, 
though, males tend to show a higher propensity for the oral burn associated with chillies than do females (see Alley \& Burroughs, 1991; Byrnes \& Hayes, 2015; Logue \& Smith, 1986; Mazur \& Booth, 1998). In fact, in some cultural contexts, like one finds in North America, the consumption of chilli is linked to a range of male personality traits (Rozin \& Schiller, 1980). ${ }^{6}$ Recently it has been demonstrated that endogenous salivary testosterone levels predict the consumption of spicy food in the laboratory (Bègue, Bricout, Boudesseul, Shankland, \& Duke, 2015). The 114 male participants who took part in the latter study were offered a $150 \mathrm{~g}$ portion of mashed potato together with a number of sachets of Tabasco sauce (a popular peppery sauce/condiment) and of salt. They were encouraged to season their food to taste before eating. The results revealed that salivary testosterone was correlated with the amount of Tabasco that participants added to their food $(r=.294, \mathrm{p}=.002)$ and to their self-rated spiciness of the food. By contrast, no such correlation was observed in the case of salt. ${ }^{7}$

One oft-reported finding in the literature is that the more an individual is exposed to capsaicin, the lower they rate the burning sensation. Such capsaicin desensitization has been shown to operate over a range of timescales from immediately after a single application of capsaicin up to periods of at least 2 weeks (cf. Green, 1989, 1991; Green \& Rentmeister-Bryant, 1998; Karrer \& Bartoshuk, 1991; Lawless, Rozin, \& Shenker, 1985; McBurney, Balaban, Christopher, \& Harvey, 1997; Nolden \& Hayes, 2017; Prescott, 1999; Prescott \& Stevenson, 1995; Prescott \& Swain-Campbell, 2000; Stevenson \& Prescott, 1994; Stevenson \& Yeomans, 1993; though see also Cowart, 1987). Perhaps unsurprisingly, the liking for chilli appears to be correlated with its consumption (Byrnes \& Hayes, 2013, 2015; Stevenson \& Yeomans, 1993). It has even been suggested that its long-term consumption may lead to chronic capsaicin desensitization (see Hayes, 2016, for a review). What is more, exposure to capsaicin can reduce the perceived intensity of other tastes as well. This is certainly true in the moment, as shown

\footnotetext{
${ }^{6}$ Indeed, on the internet, one finds many videos of people subjecting themselves to extremely hot chillies, either by eating them, (see Holmes, 2017), or, on occasion, even bathing in 1250 bottles of chilli sauce (Scott, 2016)! However, while such instances may be seen as mildly entertaining, it isn't altogether clear whether there is any theoretical advance predicated on such anecdotal observations. Some US restaurants now require their diners before trying certain particularly spicy dishes such as the "Fiery death with hate sausage pizza" mentioned in an article by Pavia (2015). And, for those who may be regretting such displays of masculinity, the top recommendations to help reduce the ensuing burn (albeit temporarily) is it drink something ice cold, as below a certain temperature the signalling no longer occurs. Stevens and Lawless (1986) also found that rinsing the mouth with sugar water helped too. Alternatively, you should try eating something solid and rough (rice, crackers, a spoonful of sugar or a mouthful of bread), as this helps 'distract' the nerves with another kind of signal (McGee, 1984/2004, p. 420; Wand-Tetley, 1956). Miracle fruit, if taken in advance, have also been reported to reduce the intensity of the burn associated with chilli.
}

${ }^{7}$ Note that while some people consider salt to be a spice, it is actually a mineral (Sherman \& Billing, 1999). 
by Lawless and Stevens (1984). That said, research on the longer-term consequences of eating chillies on taste (i.e., on specifically gustatory sensitivity) has yet to be conducted. ${ }^{8}$

\section{Why has piquant/spicy food become so popular?}

Thus far, the special status of capsaicin as a potentially painful but desirable food attribute has been outlined. A number of reasons for the profound individual differences in people's liking for (and sensory-discriminative responses to) this very particular kind of oral sensation have been discussed. But, as yet, no attempt has been made to answer the more fundamental question of why it is that people should find the painful sensation pleasurable/rewarding in the first place - Why, in other words, has piquant/spicy food become so popular in our cuisine globally. At first glance, this would seem to be a most curious aspect of our response to capsaicin-containing chillies. Over the years, a number of more-or-less plausible accounts of this phenomenon have been put forward in the literature.

\section{1) The masochistic/thrill-seeking hypothesis}

According to one popular suggestion, it is the endorphin hit, much like running a marathon, that people come to associate with the consumption of increasingly-spicy food, which they, in some sense, crave or even become 'addicted’ to (Rozin \& Schiller, 1980; see also Byrnes \& Hayes, 2015, 2016). According to Paul Rozin (1987), the oral burn from peppers may well lead to the release of endogenous opioids. It has to be said, though, that this account perhaps does a better job of explaining chilli-liking in some countries, like North America, where an ability to handle the heat has, amongst a certain section of the society, become associated with outward signs of masculinity. This account does a less good job in other cultures, like Mexico, where the consumption of chilli in a meal is a much more widespread part of the culture/cuisine (and where chillies are added to many dishes more for their flavour than for their pungency/spicy character; see Miller \& Harrison, 1991). Furthermore, it is also worth noting that while this particular suggestion often makes it into the popular press (e.g., see Gorman, 2010, for one

\footnotetext{
8 Some of the insurance companies, though, would certainly seem to believe that there are long-term consequences. At least according to the press reports of professional tasters whose taste buds have been insured for work purposes. According to one such report, the taster for Cadbury chocolate here in the UK had it written into her contract that she must avoid overly-spicy foods such as chilli and Vindaloo curry (e.g., see Daily Mail Reporter, 2016). Though, as to whether this is more of a marketing-led story than a serious scientifically-justified concern, I'll leave it to the reader to decide!
} 
such example), convincing empirical support for this hypothesis is still to be forthcoming nearly four decades after the suggestion first appeared in print.

\section{2) The antimicrobial hypothesis}

According to another suggestion, spices (in general) may originally have been added to foods in order to help kill-off bacteria and to provide protection against a range of food-borne illnesses (Sherman \& Billing, 1999; see also Liu, 1996). ${ }^{9}$ This suggestion certainly fits well with a number of observations: First-off, a growing body of evidence demonstrates that various spices can kill the bacteria that spoil many meats, and which become more prevalent as the ambient temperature increases (Billing \& Sherman, 1998). So, for example, it has been shown that the number of spices found in recipes for meat goes up with the average temperature (at least for those spices, like chilli, that have antimicrobial properties; Billing \& Sherman, 1998; Ceylan \& Fung, 2004; Cichewicz \& Thorpe, 1996; Marini, Magi, Mingoia, Pugnaloni, \& Facinelli, 2015; Molina-Torres, García-Chávez, \& Ramírez-Chávez, 1999; Omolo, Wong, Mergen, Hastings, Le, Reiland, Case, \& Baumler, 2014; Xing, Cheng, \& Yi, 2006). ${ }^{10}$ The assumption here is that the majority of these recipes became entrenched in the culture prior to the advent of widespread refrigeration. ${ }^{11}$ What is more, in those cultures that span different climatic zones, the same relationship between ambient temperature and the use of spices in meat-based recipes is observed.

However, while this account is certainly convincingly-supported by the evidence discussed by Sherman and Billing (1999), one might perhaps have expected the early cultivation of this plant to primarily have occurred far from the coast (i.e., far from readily-available sources of fresh fish/shellfish) - i.e., to help those who needed to store meat in warm temperatures. As yet,

\footnotetext{
${ }^{9}$ Sherman and Billing (1999) distinguish this ultimate (evolutionary) hypothesis from the more proximate hypothesis that spices might have been added to disguise off-taints in foods (e.g., Govindarajan, 1985). They argue that the latter account would not necessarily predict increased liking, given that people would presumably not come to like those foods that tasted good but which ended-up making them ill because they had already gone off.

${ }^{10}$ Sherman and Billing (1999) analysed the ingredients found in 93 traditional recipe books from 36 countries describing meat-based dishes. They chose to focus on meat because the cookbooks tended to include more recipes for meat, and because the antimicrobial properties of spices are likely to be more beneficial in meat than in vegetable dishes. The countries concerned had mean annual temperatures ranging between $2.8^{\circ}$ in Norway and $27.6^{\circ}$ in Thailand.

${ }^{11}$ Intriguingly, one doesn't see the same trend (or ambient temperature-dependence) for those herbs and spices (e.g., black and white pepper, and lemon and lime juice) that do not have such an antimicrobial function. Indeed, according to Sherman and Billing's (1999) own analysis, parsley and dill were the only two herbs to show a negative relationship - meaning these herbs were more common in the cuisine of cooler climes.
} 
however, the majority of the early archaeological sites (dating up to 6,000 years ago) suggesting the cultivation and consumption of chilli (and maize) are found in the Caribbean, or else on the pacific coast of South and Central America instead (Perry et al., 2007). Perhaps the early cultivation of chilli was based more on enlivening an otherwise boring, maize-based diet (cf. Martínez, 1992), whereas subsequently it was this easily-cultivatable fruit's antimicrobial properties that came to the fore in sustaining its rise.

\section{3) The thermoregulation/induced salivation hypotheses}

A third suggestion that has been put forward to explain the widespread use of chilli in the foods eaten in warmer climates is that, by inducing gustatory facial sweating, the consumption of capsaicin might play some small role in thermoregulation (e.g., Abdel-Salam, 2016; Lara, 2015; Lee, 1954). Other commentators, including chefs, meanwhile, point to capsaicin’s role as an inducer of salivation (Abdel-Salam, 2016; Rozin, 1987; Tellez, 2011), thus making it easier to consumer dry foods. However, the latter two suggestions would seem to have fallen out of favour in recent years. This is perhaps because, as noted by Rozin and Schiller (1980; see also Sherman \& Billing, 1999), many of the spices that are added to foods have no thermoregulatory (or, for that matter, salivation-inducing) function, thus, at least, arguing against this as a general account of why spices should have been added to foods.

\section{4) Medicinal/health/dietary accounts}

The consumption of chillies has served a non-culinary medicinal role a various points in history too (e.g., Cichewicz \& Thorpe, 1996; Monardes, 1577; Watcher \& Wheeland, 1989). ${ }^{12}$ At the same time, however, it has also been suggested that capsaicin, when consumed to excess, may exhibit carcinogenic properties (Surh \& Lee, 1996), though such claims have certainly not convinced everyone (e.g., see McGee, 1984/2004, p. 419). Perhaps the closest to evidence in humans comes from an epidemiological study conducted in Mexico in which those who consumed chilli pepper in their cuisine were found to be at a higher risk for gastric cancer than non-consumers of chilli (López-Carillo, Hernández Avila, \& Dubrow, 1994). Of course, being

\footnotetext{
${ }^{12}$ As Lauden and Pildrtich (1999) note: "By 1577, Nicholas Monardes, a Spanish physician who wrote one of the first treatises on New World plants, enthused that "It dooeth comforte muche, it dooeth dissolve windes, it is good for the breaste, and for theim that bee colde of complexion: it dooeth heale and comforte, strengthenyng the principall members."”
} 
merely correlational in nature, this particular study falls short in terms of convincingly demonstrating a causal role for capsaicin in cancer (though see also Lopez-Carrillo, LopezCervantes, Robles-Diaz, Ramirez-Espitia, Mohar-Betancourt, Meneses-Garcia, et al., 2003; Nilius \& Appendino, 2013). What is more, one has to presume that all of the drug companies out there who have incorporated capsaicin into their topical analgesics must have done the appropriate background toxicology research in order to reassure themselves that capsaicin is not, in fact, carcinogenic.

In fact, contrary to the very suggestion that eating chile might be deleterious to one's health, are the results of an intriguing recent study of 16,000 North Americans who had completed food questionnaires over an average of nearly 20 years. During that time nearly 5,000 of them had died. What the researchers found was that those who ate a lot of red hot chillies were $13 \%$ less likely to die during that period than those who did not, or as the authors dryly put it: "Consumption of hot red chili peppers was associated with a $13 \%$ reduction in the instantaneous hazard of death.” (Chopan \& Littenberg, 2017, p. 1; see also Lv, Qi, Yu, Yang, Guo, Chen, et al., 2015, for similar conclusions from an earlier Chinese study).

One other role for capsaicin in food that has emerged in recent years relates to the growing body of empirical research suggesting that red pepper may potentially help people to control their weight by increasing the metabolic rate and/or reducing their energy intake (e.g., Henry \& Emery, 1986; Janssens, Hursel, Martens, \& Westerterp-Plantenga, 2013; Watanabe, Kawada, \& Iwal, 1987; Watanabe, Kawada, Kurosawa, Sato, \& Iwai, 1991; WesterterpPlantenga, Smeets, \& Lejeune, 2005). So, for instance, Yoshioka, Lim, Kikuzato, Kiyonaga, Tanaka, and Shindo (1995) reported that the consumption of red pepper led to a temporary increase in metabolism amongst the males tested in one study, while those tested in another consumed less fat following the ingestion of red pepper (Yoshioka, Imanaga, Ueyama, Yamane, Kubo, \& Boivin, et al., 2004).

While such a weight-control function is unlikely to have conveyed any benefit prior to the modern era (i.e., at times when food sources would have been much scarcer than they are today), there is understandably a growing interest in capsaicin's role in potentially helping people to reduce their energy intake nowadays given the growing global obesity crisis. ${ }^{13}$ In the past, anything that may have helped our ancestors to suppress their hunger pangs might have

\footnotetext{
${ }^{13}$ In passing (if you'll excuse the pun), one should perhaps also mention the laxative properties of hot peppers in modulating energy intake (cf. Abdel-Salam, 2016; McGee, 1984/2004, p. 419).
} 
been desirable. According to Dulloo (1998, p. 494): “spices rich in capsaicinoids could therefore constitute a new class of dietary ingredients with sympathomimetic thermogenic effects." That said, much of the research on capsaicin's potential as an aid to weight management, has involved only short-term assessment (see also Doucet \& Tremblay, 1997). It will therefore be important to check that such effects do not habituate/desensitize in due course.

\section{Conclusions}

While capsaicin may well be the best-studied of chemesthetic trigeminal stimulants, it has nevertheless still attracted less attention than for any of the other basic tastes. This is rather surprising when it is considered that one in four of us eat chilli daily (Cordell \& Araujo, 1993). In this review, the phenomenal rise in popularity of this New World fruit which traces its roots back to Bolivia several thousand years ago has been highlighted. Several popular suggestions have been put forward to account for this plant's popularity in our diet (across the globe). And, taken together, these various hypotheses would jointly seem to do a better job of explaining the spread of this peculiarly piquant fruit at different points in history, than any single theory.

Specifically, the chilli plant (Capsicum) may initially have been cultivated because of its role as a flavour enhancer (possibly spicing-up a diet that was heavily maize-based). Its role as a rich source of Vitamins A and C), and its ease of cultivation, as a plant that isn't attacked by land-based herbivores, given that the chilli plant is a low-growing shrub with fruit available to mammals and birds (Tewksbury \& Nabham, 2001), might also have played a role. Furthermore, its antimicrobial properties, when widespread refrigeration wasn't an option, would also seem to have been important. The spread of chilli around the world may have been helped by its ability to trigger the release of endogenous opioids in those who consume it (this the masochism/sensation-seeking hypothesis). Such an account would seem to do a better job of explain people's behaviour around food more meaningfully in some cultures (like North America, where the account, in fact, originated) than in Mexico, where chillies are added to a very wide range of dishes for their flavour as much as (or perhaps 'rather than') for their piquancy (e.g., Adapon, 2008; Miller \& Harrison, 1991; see also Calvino, 2009). Indeed, ultimately, it is always important to remember the cultural component to people's enjoyment of / response to chilli, as this complicates an easy understanding of, and generalizations about, what many people obviously agree to be one of the most desirable of oral sensations. Other hypotheses that have attracted some limited support over the decades are the thermoreulation 
and salivation-inducing accounts. However, they seem to have fallen out of favour in recent years. And, finally, there is a growing awareness of the chile plant's potential role in promoting health, well-being, and possibly also being used to help people control their appetite (and hence possibly their weight). That said, further long-term studies are needed in order to really understand the potential importance/relevance of such approaches. 


\section{REFERENCES}

Abdel-Salam, O. M. E. (2016). Preference for hot pepper: A complex interplay of personal, cultural, and pharmacological effects. Temperature (Austin), 3(1), 39-40.

Adapon, J. (2008). Culinary art and anthropology. Oxford, UK: Berg.

Allen, J. S. (2012). The omnivorous mind: Our evolving relationship with food. London, UK: Harvard University Press.

Alley, T. R., \& Burroughs, W. J. (1991). Do men have stronger preferences for hot, unusual, and unfamiliar foods? Journal of General Psychology, 118, 201-213.

Barchenger, D. W., \& Bosland, P. W. (2016). Exogenous applications of capsaicin inhibits seed germination of Capsicum annuum. Scientia Horticulturae, 203, 29-31.

Bartoshuk, L. M. (1993). The biological basis of food perception and acceptance. Food Quality \& Preference, 4, 21-32.

Bègue, L., Bricout, V., Boudesseul, J., Shankland, R., \& Duke, A. A. (2015). Some like it hot: Testosterone predicts laboratory eating behavior of spicy food. Physiology and Behavior, 139, 375-377.

Billing, J., \& Sherman, P. W. (1998). Antimicrobial functions of spices: Why some like it hot. Quarterly Review of Biology, 73, 3-49.

Bloom, P. (2011). How pleasure works: Why we like what we like. London, UK: Vintage.

Bodkin, H. (2017). Hottest chilli pepper in the world accidentally created by Welsh farmer. The Telegraph, May 17 ${ }^{\text {th }}$. http://www.telegraph.co.uk/news/2017/05/17/welsh-grown-hottestever-chilli-line-chelsea-flower-show-prize/.

Bosland, P. W., \& Votava, E. J. (2012). Peppers: Vegetable and spice capsicums (2 ${ }^{\text {nd }}$ Ed.). Oxfordshire, UK; CAB International.

Byrnes, N. K., \& Hayes, J. E. (2013). Personality factors predict spicy food liking and intake. Food Quality and Preference, 28, 213-221.

Byrnes, N. K., \& Hayes, J. E. (2015). Gender differences in the influence of personality traits on spicy food liking and intake. Food Quality and Preference, 42, 12-19.

Byrnes, N., \& Hayes, J. E. (2016). Behavioral measures of risk tasking, sensation seeking and sensitivity to reward may reflect different motivations for spicy food liking and consumption. Appetite, 103, 411-422.

Calvino, I. (2009). Under the jaguar sun (translated by W. Weaver). London, UK: Penguin.

Caterina, M. J., Schumacher, M. A., Tominaga, M., Rosen, T. A., Levine, J. D., \& Julius, D. (1997). The capsaicin receptor: A heat-activated ion channel in the pain pathway. Nature, 389, 816-824.

Ceylan, E., \& Fung, D. Y. C. (2004). Antimicrobial activity of spices. Journal of Rapid Methods and Automation in Microbiology, 12, 1-55. 
Chopan, M., \& Littenberg, B. (2017). The association of hot red chili pepper consumption and mortality: A large population-based cohort study. PLOS ONE, 12(1): e0169876. https://doi.org/10.1371/journal.pone.0169876

Cichewicz, R. H., \& Thorpe, P. A. (1996). The antimicrobial properties of chile peppers (Capsicum species) and their use in Mayan medicine. Journal of Ethnopharmacology, 52, 6170.

Cordell, G. A., \& Araujo, O. E. (1993). Capsaicin: Identification, nomenclature, and pharmacotherapy. Annual Pharmacotherapy, 27, 330-336.

Cowart, B. J. (1987). Oral chemical irritation: Does it reduce perceived taste intensity? Chemical Senses, 12, 467-479.

Daily Mail Reporter (2016). Chocolate expert’s £1m palate: Cadbury’s worker has tastebuds insured - and must now avoid vindaloos and chilli peppers. Daily Mail Online, September $\mathbf{6}^{\text {th }}$. http://www.dailymail.co.uk/news/article-3775150/Chocolate-expert-s-1m-palate-Cadbury-sworker-tastebuds-insured-avoid-vindaloos-chilli-peppers.html.

Dalton, P., \& Byrnes, N. (2016). Psychology of chemesthesis - why would anyone want to be in pain? In S. T. McDonald, D. A. Boilliet, \& J. E. Hayes (Eds.), Chemesthesis: Chemical touch in food and eating (pp. 8-31). Oxford, UK: Wiley-Blackwell.

Doucet, E., \& Tremblay, A. (1997). Food intake, energy balance and body weight control. European Journal of Clinical Nutrition, 51, 846-855.

Dulloo, A. G. (1998). Spicing fat for combustion. British Journal of Nutrition, 80, 493-494.

Eshbaugh, W. H., Janick, J., \& Simon, J. E. (1993). History and exploitation of a serendipitous new crop discovery. New crops (pp. 132-139). New York, NY: Wiley.

Farrell, K. T. (1990). Spices, condiments, and seasonings ( $2^{\text {nd }}$ Ed.). New York, NY: Van Nostrand Reinhold.

Fernández-Armesto, F. (1991). Columbus. Oxford, UK: Oxford University Press.

Fraenkel, G. S. (1959). The raison d'être of secondary plant substances. Science, 129, 14661470 .

Galef, B. G. (1989). Enduring social enhancement of rats' preferences for the palatable and the piquant. Appetite, 13, 81-92.

Garneau, N. L., Nuessle, T. M., Sloan, M. M., Santorico, S. A., Coughlin, B. C., \& Hayes, J. E. (2014). Crowdsourcing taste research: Genetic and phenotypic predictors of bitter taste perception as a model. Frontiers of Integrative Neuroscience, 8:33.

Gorman, J. (2010). A perk of our evolution: Pleasure in pain of chilies. The New York Times, September

$20^{\text {th }}$. http://www.nytimes.com/2010/09/21/science/21peppers.html?pagewanted=all.

Govindarajan, V. S. (1985). Capsicum production, technology, chemistry, and quality. Part I: History, botany, cultivation, and primary processing. CRC Critical Reviews in Food Science and Nutrition, 22, 109-176.

Govindarajan, V. S., \& Sathyanarayana, M. N. (1991) Capsicum-production, technology, chemistry, and quality. Part V. Impact on physiology, pharmacology, nutrition, and metabolism: structure, pungency, pain, and desensitization sequences. CRC Critical Reviews in Food Science and Nutrition, 29, 435-474. 
Green, B. G. (1989). Capsaicin sensitization and desensitization on the tongue produced by brief exposures to a low concentration. Neuroscience Letters, 107, 173-178.

Green, B. G. (1991). Temporal characteristics of capsaicin sensitization and desensitization on the tongue. Physiology and Behavior, 49, 501-505.

Green, B. (1996). Chemesthesis: Pungency as a component of flavor. Trends in Food Science and Technology, 7, 415-420.

Green, B. G. (2016). Introduction: what is chemesthesis? In S. T. McDonald, D. A. Boilliet, \& J. E. Hayes (Eds.), Chemesthesis: Chemical touch in food and eating (pp. 1-31). Oxford: Wiley-Blackwell.

Green, B. G., \& Hayes, J. E. (2003). Capsaicin as a probe of the relationship between bitter taste and chemesthesis. Physiology and Behavior, 79, 811-821.

Green, B. G., \& Hayes, J. E. (2004). Individual differences in perception of bitterness from capsaicin, piperine and zingerone. Chemical Senses, 29, 53-60.

Green, B. G., \& Rentmeister-Bryant, H. (1998). Temporal characteristics of capsaicin desensitization and stimulus-induced recovery in the oral cavity. Physiology and Behavior, 65, 141-149.

Hayes, J. E. (2016). Types of chemesthesis I. Pungency and burn: Historical perspectives, word usage, and temporal characteristics. In S. T. McDonald, D. A. Boilliet, \& J. E. Hayes (Eds.), Chemesthesis: Chemical touch in food and eating (pp. 92-105). Oxford, UK: Wiley-Blackwell.

Henry, C. J. K., \& Emery, B. (1986). Effect of spiced food on metabolic rate. Human Nutrition Clinical Nutrition, 40C, 165-168.

Holmes, S. (2017). Do fear the REAPER! Hilarious moment coal miner eats the world's HOTTEST chili pepper for a bet - then suffers for three minutes as his co-workers taunt. Daily Mail Online, July $\mathbf{1 9}^{\text {th }}$. http://www.dailymail.co.uk/news/article-4710920/Moment-coalminer-eats-world-s-hottest-chili-pepper.html.

Janssens, P. L. H. R., Hursel, R., Martens, E. A. P., \& Westerterp-Plantenga, M. S. (2013). Acute effects of capsaicin on energy expenditure and fat oxidation in negative energy balance. PLoS One, 8, e67786.

Jordt, S.-E., \& Julius, D. (2002). Molecular basis for species-specific sensitivity to "hot" chili peppers. Cell, 108, 421-430.

Karrer, T., \& Bartoshuk, L. (1991). Capsaicin desensitization and recovery on the human tongue. Physiology \& Behavior, 49, 757-764.

Karrer, T., Bartoshuk, L. M., Conner, E., Fehrenbaker, S., Grubin, D., \& Snow, D. (1992). PROP status and its relationship to the perceived burn intensity of capsaicin at different tongue loci. Chemical Senses, 17, 649.

Lara, A. (2015). Affect, heat and tacos. A speculative account of thermoception. The Senses and Society, 10, 275-297.

Laudan, R., \& Pilcher, J. M. (1999). Chiles, chocolate, and race in New Spain: Glancing backward to Spain or looking forward to Mexico? Eighteenth Century Life, 23(2), 59-70.

Lawless, H. (1989). Pepper potency and the forgotten flavor sense. Food Technology, 11, 52, 57-58. 
Lawless, H., Rozin, P., \& Shenker, J. (1985). Effects of oral capsaicin on gustatory, olfactory and irritant sensations and flavor identification in humans who regularly or rarely consume chili pepper. Chemical Senses, 10, 579-589.

Lawless, H., \& Stevens, D. A. (1984). Effects of oral chemical irritation on taste. Physiology \& Behavior, 32, 995-998.

Lee, T. (1954). Physiological gustatory sweating in a warm climate. The Journal of Physiology, 124, 528-542.

Lembeck, F. (1987). Columbus, capsicum and capsaicin: Past, present and future. Acta Physiologica Hungarica, 69, 256-273.

Liu, Z. H. (1996). Antibacterial activity of spice extracts against food-related bacteria. Journal of the Faculty of Applied Biolical Science - Hiroshima University, 35, 181-190.

Logue, A. W., \& Smith, M. E. (1986). Predictors of food preferences in adult humans. Appetite, 7, 109-125.

Lomelí, A. (1991). El arte de cocinar con chile (Rev. Ed., originally El chile y otras picantes). Mexico City: Libros de Contenido.

López-Carillo, L., Hernández Avila, M., \& Dubrow, R. (1994). Chili pepper consumption and gastric cancer in Mexico: A case control study. American Journal of Epidemiology, 139, 263271.

Lopez-Carrillo, L., Lopez-Cervantes, M., Robles-Diaz, G., Ramirez-Espitia, A., MoharBetancourt, A., Meneses-Garcia, A., Lopez-Vidal, Y., \& Blair, A. (2003). Capsaicin consumption, Helicobacter pylori positivity and gastric cancer in Mexico. International Journal of Cancer, 106, 277-282.

Ludy, M. J., \& Mattes, R. D. (2012). Comparison of sensory, physiological, personality, and cultural attributes in regular spicy food users and non-users. Appetite, 58, 19-27.

Lv, J., Qi, L., Yu, C., Yang, L., Guo, Y., Chen, Y., et al. (2015). Consumption of spicy foods and total and cause specific mortality: Population based cohort study. BMJ (Clinical Research Ed.), 351:h3942. Epub 2015/08/ 06.

Marini, E., Magi, G., Mingoia, M., Pugnaloni, A., \& Facinelli, B. (2015). Antimicrobial and anti-virulence activity of capsaicin against erythromycin-resistant, cell-invasive Group A Streptococci. Frontiers in Microbiology, 6:1281.

Martínez, Z. (1992). Food from my heart: Cuisines of Mexico remembered and reimagined. New York, NY: MacMillan.

Mazur, A., \& Booth, A. (1998). Testosterone and dominance in men. Behavioural \& Brain Sciences, 21, 353-397.

McBurney, D. H., Balaban, C. D., Christopher, D. E., \& Harvey, C. (1997). Adaptation to capsaicin within and across days. Physiology and Behavior, 61, 181-190.

McGee, H. (1984/2004). McGee on food and cooking: The science and lore of the kitchen (rev. ed.). New York, NY: Scribner.

Miller, I. J., \& Reedy, D. P. (1990). Variations in human taste bud density and taste intensity perception. Physiology and Behavior, 47, 1213-1219.

Miller, M., \& Harrisson, J. (1991). The great chile book. Berkeley, CA: Ten Speed Press. 
Molina-Torres, J., García-Chávez, A., \& Ramírez-Chávez, E. (1999). Antimicrobial properties of alkamides present in flavouring plants traditionally used in Mesoamerica: Affinin and capsaicin. Journal of Ethnopharmacology, 64, 241-248.

Monardes, N. (1577). Joyfull newes out of the new founde worlde (trans. J. Frampton; Ed. S. Gaselee; London, 1925, I, 48.)

Morley, K. (2017). Music makes curries taste 10pc spicier, scientists find. The Daily Telegraph, March 12 ${ }^{\text {th }}$. http://www.telegraph.co.uk/news/2017/03/12/music-makes-curries-taste-10pcspicier-scientists-find/.

Muñoz Zurita, R. (1996). Los chiles rellenos en México: Antología de recetas [Stuffed chiles in Mexico: An anthology of recipes]. Mexico City: UNAM.

Nasrawi, C. W., \& Pangborn, R. M. (1990). Temporal gustatory and salivary responses to capsaicin upon repeated stimulation. Physiology and Behavior, 47, 611-615.

Nilius, B., \& Appendino, G. (2013). Spices: The savory and beneficial science of pungency. Reviews of Physiology, Biochemistry and Pharmacology, 164, 1-76. Epub 2013/04/23. doi: 10.1007/112_2013_11 PMID: 23605179

Nolden, A. A., \& Hayes, J. E. (2017). Perceptual and affective responses to sampled capsaicin differ by reported intake. Food Quality and Preference, 55, 26-34.

Omolo, M. A., Wong, Z., Mergen, A. K., Hastings, J. C., Le, N. C., Reiland, H. A., Case, K. A., \& Baumler, D. J. (2014) Antimicrobial properties of chili peppers. Journal of Infectious Diseases Therapy, 2:145.

Paran, I., \& van der Knapp, E. (2007). Genetic and molecular regulation of fruit and plant domestication traits in tomato and pepper. Journal of Experimental Biology, 58, 3841-3852.

Pavia, W. (2018). Diners must sign waiver before eating chilli pizza. The Times, January $\mathbf{1 9}^{\text {th }}$, 30.

Perry, L., Dickau, R., Zarrillo, S., Hoist, I., Pearsall, D. M., Piperno, D. R., et al. (2007). Starch fossils and the domestication and dispersal of chili peppers (Capsicum spp. L.) in the Americas. Science, 315, 986-988.

Prescott, J. (1999). The generalizability of capsaicin sensitization and desensitization. Physiology and Behavior, 66, 741-749.

Prescott, J., \& Swain-Campbell, N. (2000). Responses to repeated oral irritation by capsaicin, cinnamaldehyde and ethanol in PROP tasters and non-tasters. Chemical Senses, 25, 239-246.

Nabhan, G. P. (2004). Why some like it hot. Food, genes and cultural diversity. Washington: Island Press.

Prescott, J., \& Stevenson, R. J. (1995). Effects of oral chemical irritation on tastes and flavors in frequent and infrequent users of chili. Physiology \& Behavior, 58, 1117-1127.

Rozin, P. (1987). Psychobiological perspectives on food preferences and avoidances. In M. Harris \& E. B. Ross (Eds.), Food and evolution: Toward a theory of human food habits (pp. 181-205). Philadelphia, PA: Temple University Press.

Rozin, P. (1990). Getting to like the burn of chili pepper: Biological, psychological, and cultural perspectives. In B. G. Green, F. R. Mason, \& M. R. Kare (Eds.), Chemical senses, Vol 2: Irritation (pp. 217-228). New York, NY: Dekker.

Rozin, P., Ebert, L., \& Schull, J. (1982). Some like it hot: A temporal analysis of hedonic responses to chili pepper. Appetite, 3, 13-22. 
Rozin, P. \& Kennel, K. (1983) Acquired preference for piquant foods by chimpanzees. Appetite, 4, 69-77.

Rozin, P., Mark, M., \& Schiller, D. (1981). The role of desensitization to capsaicin in chili pepper ingestion and preference. Chemical Senses, 6, 23-31.

Rozin, P., \& Schiller, D. (1980). The nature and acquisition of a preference for chili peppers by humans. Motivation and Emotion, 4, 77-101.

Schivelbusch, W. (2005). Tastes of paradise: A social history of spices, stimulants, and intoxicants [translated by David Jacobson]. New York, NY: Pantheon. [The relevant section of this book has been reprinted as Schivelbusch, W. (2005). Spices: Tastes of paradise. In C. Korsmeyer (Ed.), The taste culture reader: Experiencing food and drink (pp. 123-130). Oxford, UK: Berg.]

Scott, F. (2016). Flaming idiot! Crazy moment prankster screams in pain after bathing himself (and dunking his head) in 1,250 bottles of hot chilli sauce. Daily Mail Online, August $\mathbf{2 6}^{\text {th }}$. http://www.dailymail.co.uk/news/article-3760515/Crazy-moment-prankster-screams-painbathing-dunking-head-1-250-bottles-hot-chilli-sauce.html.

Scoville, W. L. (1912). Note on capsicums. Journal of the American Pharmaceutical Association, 1, 453-454.

Sherman, P. W., \& Billing, J. (1999). Darwinian gastronomy: Why we use spices. Spices taste good because they are good for us. BioScience, 49, 453-463.

Spence, C. (2012). Auditory contributions to flavour perception and feeding behaviour. Physiology \& Behaviour, 107, 505-515.

Spence, C., Smith, B., \& Auvray, M. (2015). Confusing tastes and flavours. In D. Stokes, M. Matthen, \& S. Biggs (Eds.), Perception and its modalities (pp. 247-274). Oxford, UK: Oxford University Press.

Standage, T. (2009). An edible history of humanity. London, UK: Atlantic Books.

Stevens, D. A. (1990). Personality variables in the perception of oral irritation and flavor. In B. G. Green, F. R. Mason, \& M. R. Kare (Eds.), Chemical senses, Vol 2. Irritation (pp. 217228). New York, NY: Marcel Dekker.

Stevens, D. A., \& Lawless, H. (1986). Putting out the fire: Effects of tastants on oral chemical irritation. Perception \& Psychophysics, 39, 346-350.

Stevenson, R. J., \& Boakes, R. A. (2004). Sweet and sour smells: Learned synaesthesia between the senses of taste and smell. In G. A. Calvert, C. Spence, \& B. E. Stein (Eds.), The handbook of multisensory processing (pp. 69-83). Cambridge, MA: MIT Press.

Stevenson, R. J., Boakes, R. A., \& Prescott, J. (1998). Changes in odor sweetness resulting from implicit learning of a simultaneous odor-sweetness association: An example of learned synaesthesia. Learning and Motivation, 29, 113-132.

Stevenson, R. J., \& Prescott, J. (1994). The effects of prior experience with capsaicin on ratings of its burn. Chemical Senses, 19, 651-656.

Stevenson, R. J., \& Yeomans, M. R. (1993). Differences in ratings of intensity and pleasantness for the capsaicin burn between chili likers and non-likers - implications for liking development. Chemical Senses, 18, 471-482.

Surh, Y.-J., \& Lee, S. S. (1996). Capsaicin in hot chili pepper: Carcinogen, co-carcinogen, or anticarcinogen? Food and Chemical Toxicology, 34, 313-316. 
Tellez, Z. (2011). Picante y capsaícina. Letras libres video [online]. Available from: http://www.youtube.com/watch?v=5Z0b-V4k3OKY\&feature=youtube_gdata_player.

Terasaki, M., \& Imada, S. (1988). Sensation seeking and food preferences. Personality \& Individual Differences, 9, 87-93.

Tewksbury, J. J., \& Nabhan, G. P. (2001). Seed dispersal—directed deterrence by capsaicin in chilies. Nature, 412, 403-404.

Tewksbury, J. J., Nabhan, G. P., Norman, D., Suzan, H., Tuxill, J., \& Donovan, J. (1999). In situ conservation of wild chilies and their biotic associates. Conservation Biology, 13, 98-107.

Tewksbury, J. J., Reagan, K. M., Machnicki, N. J., Carlo, T. A., Haak, D. C., Calderón Peñaloza, A. L., \& Levey, D. J. (2008). Evolutionary ecology of pungency in wild chilies. Proceedings of the National Academy of Sciences of the USA, 105, 11808-11811.

Törnwall, O., Silventoinen, K., Kaprio, J., \& Tuorila, H. (2012). Why do some like it hot? Genetic and environmental contributions to the pleasantness of oral pungency. Physiology \& Behavior, 107, 381-389.

van Rhijn, P. (1993). La cocina del chile [The chile kitchen]. Mexico City: Suari.

Wand-Tetley, J. I. (1956). Historical methods of counter-irritation. Annual Review of Physiology \& Medicine, 3, 90-98.

Watanabe, A., Kawada, T., \& Iwai, K. (1987). Enhancement by capsaicin of energy metabolism in rats through secretion of catecholamine from adrenal medulla. Agriculture and Biological Chemistry, 51, 75-79.

Watanabe, A., Kawada, T., Kurosawa, M., Sato, A., \& Iwai, K. (1991). Thermogenic action of capsaicin and its analogs. In M. Suzuki (Ed.), Obesity: Dietary factors and control (pp. 67-77). Tokyo and Basel: Japan Scientific Societies Press and S Karger AG.

Watcher, M. A., \& Wheeland, R. G. (1989). The role of topical agents in the healing of fullthickness wounds. Journal of Dermatological Surgery and Oncology, 15, 1188-1195.

Weil, A. (1976). Hot! Hot! I: Eating chilies. Journal of Psychedelic Drugs, 8, 83-86.

Westerterp-Plantenga, M. S., Smeets, A., \& Lejeune, M. P. G. (2005). Sensory and gastrointestinal satiety effects of capsaicin on food intake. International Journal of Obesity (London), 29, 682-688.

Wheeler, S. C., \& Berger, J. A. (2007). When the same prime leads to different effects. Journal of Consumer Research, 34, 357-368.

Yoshioka, M., Imanaga, M., Ueyama, H., Yamane, M., Kubo, Y., Boivin, A., et al. (2004). Maximum tolerable dose of red pepper decreases fat intake independently of spicy sensation in the mouth. British Journal of Nutrition, 91, 991-995

Yoshioka, M., Lim, K., Kikuzato, S., Kiyonaga, A., Tanaka, H., \& Shindo, M. (1995). Effects of red-pepper diet on the energy metabolism in men. Journal of Nutritional Science \& Vitaminology (Tokyo), 41, 647-656.

Xing, F. B., Cheng, G. X., \& Yi, K. K. (2006). Study on the antimicrobial activities of the capsaicin microcapsules. Journal of Applied Polymer Science, 102, 1318-1321.

Zohary, D., \& Hopf, M. (1994). Domestication of plants in the Old World: The origin and spread of cultivated plants in West Asia, Europe, and the Nile Valley ( ${ }^{\text {nd }}$ Ed.). Oxford, UK: Oxford University Press. 